\title{
Production, metabolism, and follicular dynamics in multiparous dairy cows fed diets providing different amounts of metabolizable protein prepartum and postpartum
}

\author{
J. P. Underwood, ${ }^{1 *}$ J. H. Clark, ${ }^{1} \odot$ F. C. Cardoso, ${ }^{1} \odot$ P. T. Chandler, ${ }^{2 *}$ and J. K. Drackley ${ }^{1} \dagger \odot$ \\ ${ }^{1}$ Department of Animal Sciences, University of Illinois, Urbana 61801 \\ ${ }^{2}$ Chandler and Associates, Dresden, TN 38225
}

\begin{abstract}
Our objectives were (1) to determine whether increasing metabolizable protein (MP) supply above requirements in late-gestation cows would benefit health, milk production, and reproduction; (2) to determine whether an increased supply of MP postpartum affects production; and (3) to determine whether supply of MP prepartum interacts with MP supply postpartum. Pregnant nonlactating cows $(\mathrm{n}=60)$ blocked by expected parturition date were assigned to 1 of 3 prepartum diets from $21 \mathrm{~d}$ prepartum to parturition: $12 \%$ crude protein (CP) soybean meal (SBM) supplement (LSB); $15 \%$ CP SBM supplement (HSB); and 15\% CP SBM plus animal-marine protein supplement (HMP). Diets were formulated to supply an estimated 924, 988 , and $1,111 \mathrm{~g} / \mathrm{d}$ of MP, respectively, at $11.5 \mathrm{~kg}$ of dry matter intake (DMI). After parturition, cows received diets containing 18\% CP, either from SBM (SB) or SBM plus animal-marine protein (AMP) supplements, that provided 2,056 (SB) or 2,293 g/d (AMP) of $\mathrm{MP}$ at $21 \mathrm{~kg}$ of DMI; thus, treatments were in a 3 $\times 2$ factorial arrangement. Milk production and DMI were recorded for $63 \mathrm{~d}$ postpartum. Prepartum DMI was lower at wk -3 for cows fed LSB compared with those fed HSB or HMP. Postpartum DMI did not differ significantly between cows fed SB and those fed AMP (20.8 vs. $19.6 \mathrm{~kg} / \mathrm{d})$. Milk production did not differ due to prepartum diets or postpartum diets. Milk fat and protein percentages were not affected by prepartum or postpartum diets. Cows fed AMP postpartum tended to produce more milk fat, but $4 \%$ fat-corrected milk (FCM) did not differ from SB-supplemented cows (33.6 $\mathrm{kg} / \mathrm{d}$ vs. $32.2 \mathrm{~kg} / \mathrm{d}$ ). Gross feed efficiency (FCM/DMI) was greater for cows fed AMP postpartum (1.82 vs.
\end{abstract}

Received July 12, 2021.

Accepted January 16, 2022.

*Deceased.

†Corresponding author: drackley@illinois.edu
1.68). Prepartum concentrations of urea $\mathrm{N}$ in plasma were lower for LSB than for HSB and HMP, and HSB was greater than HMP. Postpartum concentrations of nonesterified fatty acids and $\beta$-hydroxybutyrate were greater for cows fed AMP postpartum than for those fed SB. Postpartum urea $\mathrm{N}$ was higher for SB than for $\operatorname{AMP}(14.4$ vs. $12.5 \mathrm{mg} / \mathrm{dL}$ ). Concentration of total protein in plasma was greater postpartum for cows fed HSB or HMP prepartum than for those fed LSB, and was greater postpartum for cows fed AMP than for those fed SB. Hepatic concentrations of total lipids and triglyceride did not differ among treatments. Hepatic glycogen was greater postpartum for cows fed SB postpartum. Feeding HSB or HMP increased the number of follicles 6 to $9 \mathrm{~mm}$ in diameter compared with LSB. The size of the largest follicle was increased by HMP compared with HSB. In conclusion, increasing the amount of MP fed to cows during the last $21 \mathrm{~d}$ prepartum did not affect milk production or BCS but increased plasma total protein concentration. Follicular dynamics were improved by increasing the amount of MP prepartum. Feeding HMP prepartum improved follicular dynamics prepartum and increased milk fat yield in wk 1. Feeding AMP postpartum increased efficiency of FCM production and plasma total protein. We found few interactions between prepartum and postpartum MP supply.

Key words: metabolizable protein, metabolism, transition period, follicular dynamics

\section{INTRODUCTION}

Adequate dietary MP is necessary in transition cows to meet the needs of fetal and placental growth, mammary development and lactogenesis, and maintenance (Bell et al., 2000). The NRC (2001) calculated MP requirements for dry Holstein cows to be 800 to $900 \mathrm{~g} / \mathrm{d}$. Addition of a requirement for mammary growth would increase that amount to around 1,000 g/d (Bell et al., 2000). Some nutritionists have recommended amounts 
of MP as high as 1,350 g/d for multiparous cows because of limited data indicating possible health benefits (Van Saun and Sniffen, 2014).

Given the possibility that MP requirements are greater than NRC (2001) recommendations, researchers have fed diets with greater predicted MP supply in an attempt to improve the transition to lactation, increase milk production, and improve health and reproduction. Husnain and Santos (2019) performed a meta-analysis on studies that supplied greater $\mathrm{CP}$ and MP to primiparous and multiparous cows before calving. They showed that primiparous cows benefited from increasing MP supplies to at least 1,100 g/d, whereas multiparous cows did not respond to increased MP supply $>800 \mathrm{~g} / \mathrm{d}$ except for protein yield from cows that produced $>36$ $\mathrm{kg} / \mathrm{d}$ of milk in early lactation. Others have argued that health in multiparous cows might benefit from greater prepartum MP supply, but data are scarce (Lean et al., 2013; Van Saun and Sniffen, 2014). Curtis et al. (1985) determined that feeding protein above recommendations during the final 3 wk prepartum was associated with decreased risk of retained placenta. Lee et al. (2019) found that supplemental rumen-protected Lys and Met fed prepartum decreased SCC in fresh cows. Reproduction also might be influenced by prepartum protein nutrition. Exposure of follicles to excessive N prepartum might impair follicle function and fertility in the postpartum period. Excess dietary protein might be detrimental to oocyte development (Butler et al., 1996).

Diets for dry cows are often low in energy and fermentable carbohydrates, with the result that rumen microbial protein synthesis might not be adequate to meet the increased demands for MP (Kokkonen, 2014). Moreover, DMI often decreases before parturition, which would lead to decreased MP supply (NRC, 2001). Feeding excessive RDP in an attempt to meet MP needs results in excretion of unused $\mathrm{N}$ as urea, thereby wasting $\mathrm{N}$ and energy; thus, RDP should not be supplied over the amount needed to maximize rumen microbial protein synthesis (ca. 10\% of DM; NRC, 2001). Protein sources high in RUP and providing a high-quality profile of AA should be used to supply the remaining MP over that provided by microbial protein synthesis (NRC, 2001). Widely used sources of RUP include heat-treated soybean meal (SBM) and animal proteins such as fish meal and blood meal. One such high-RUP source is Prolak (H. J. Baker \& Bro. Inc.), which is a blend of blood meal, fish meal, feather meal, meat and bone meal, and rumen-protected Met containing $76 \% \mathrm{CP}$ (DM basis). As determined by in situ analyses at an assumed outflow rate of $6 \% / \mathrm{h}$, the effective rumen degradability of Prolak was 28.5\%, compared with $66.9 \%$ for SBM (Santos et al., 1999). In-
Table 1. Composition of EAA in soybean meal (SBM) and Prolak $(\mathrm{H}$. J. Baker \& Bro. Inc.; g of AA/100 g of CP)

\begin{tabular}{lcc}
\hline EAA & SBM $^{1}$ & Prolak $^{2}$ \\
\hline Arg & 7.8 & 5.8 \\
His & 2.9 & 3.5 \\
Ile & 5.1 & 3.0 \\
Leu & 8.4 & 9.2 \\
Lys & 7.1 & 6.1 \\
Met & 1.6 & 1.6 \\
Phe & 5.4 & 5.0 \\
Thr & 4.2 & 3.9 \\
Trp & 1.4 & $\mathrm{ND}^{3}$ \\
Val & 5.5 & 6.8 \\
\hline
\end{tabular}

${ }^{1}$ Boucher et al. (2009).

${ }^{2}$ Raggio et al. (2004).

${ }^{3}$ Not determined.

creasing Prolak in the diet increased MP supply to the intestine and increased portal delivery of EAA (Raggio et al., 2004). The EAA profile of Prolak compared with that of SBM is shown in Table 1.

In contrast to prepartum MP supply, supplementation of protein sources high in RUP to increase postpartum MP supply generally has improved production and indicators of metabolic status (Komaragiri and Erdman, 1997; Law et al., 2009; Amanlou et al., 2017). Larsen et al. (2014) reported that postruminal infusion of casein in fresh cows increased milk production, plasma protein concentration, and measures of immune function. Zhang et al. (2015) reported that cows fed $7.2 \%$ added extruded full-fat soybeans (which increased $\mathrm{CP}$ and predicted MP) postpartum had greater milk yield. Carder and Weiss (2017) fed diets higher in MP and with improved estimated EAA balance. Feeding additional protein increased the concentration and yield of milk fat, milk protein concentration, and ECM yield. Additional protein also decreased concentrations of 3-methylhistidine in plasma, suggesting less body protein mobilization.

Lean et al. (2013) speculated that increasing MP in prepartum diets to greater than NRC (2001) requirements would increase labile body protein stores and lessen the effects of postpartum MP supply, whereas lesser MP supply prepartum would highlight the importance of MP in the immediate postpartum period. In addition to labile protein reserves, such interactions could be important because of possible adaptations in liver or other tissues to AA excess or deficit (Hartwell et al., 2001). We are aware of only one study that has considered the potential interaction of prepartum MP supply with postpartum MP supply (Amirabadi Farahani et al., 2019). In that study, cows responded to greater MP postpartum only when fed a lower MP diet prepartum, supporting the proposal by Lean et al. (2013). 
Table 2. Ingredient composition of diets

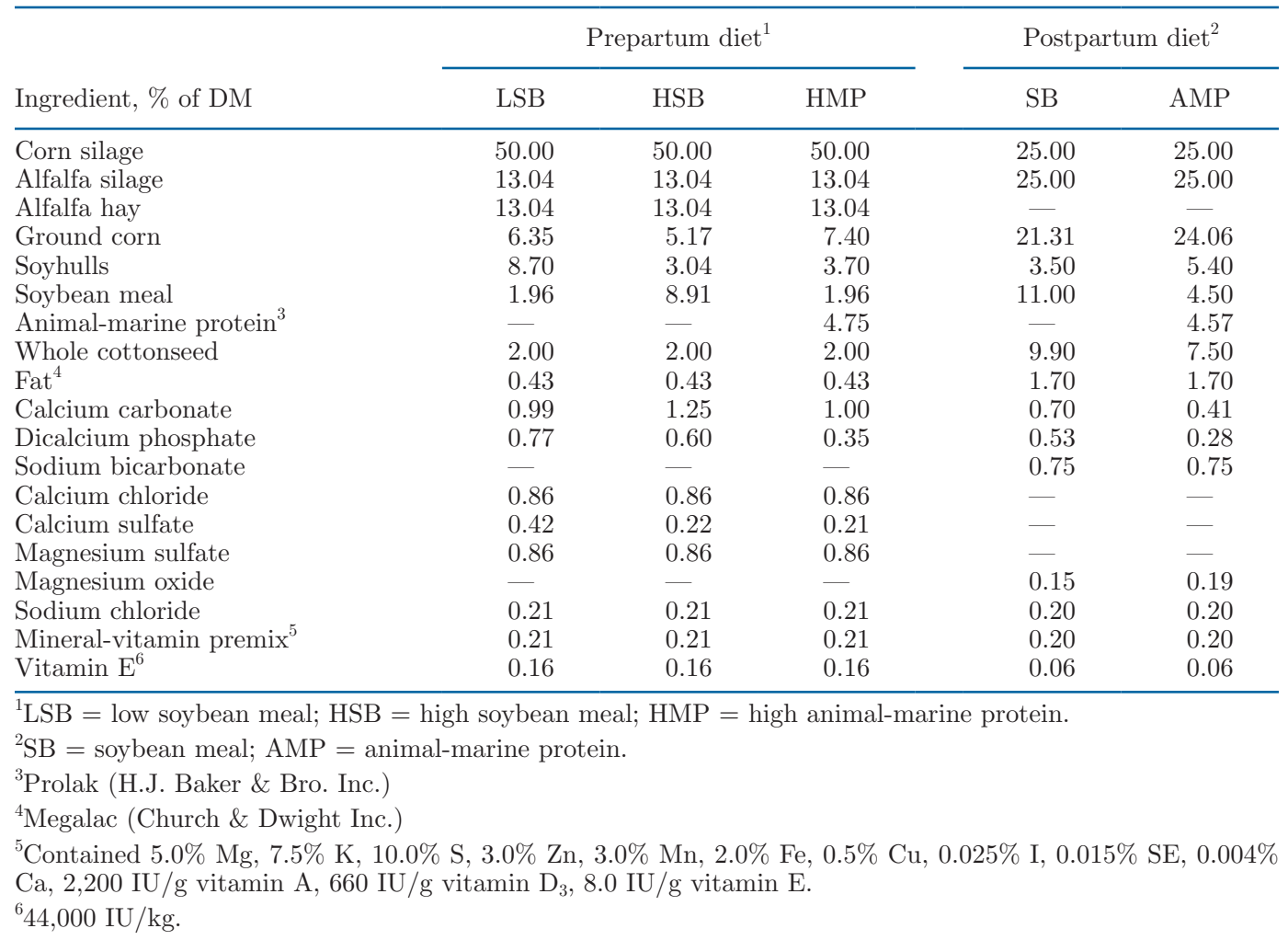

Three hypotheses were tested in this experiment. First, we predicted that a higher MP diet fed prepartum would improve milk yield, metabolism, and follicular dynamics. Second, we predicted that feeding a higher MP diet postpartum would boost milk production. Finally, our third hypothesis was that feeding a diet with greater MP supply postpartum would be of greater benefit to cows fed lower-MP diets prepartum, and vice versa. The objective of our study was to evaluate different amounts of dietary MP for multiparous cows during the periparturient period.

\section{MATERIALS AND METHODS}

All procedures were approved by the University of Illinois Animal Care and Use Committee (Urbana, IL). Sixty multiparous Holstein cows were used in a randomized complete block design. Cows were blocked according to expected parturition date and randomly assigned to 1 of 3 experimental groups with $n=20$ per treatment, which were fed different amounts of dietary MP during the last $3 \mathrm{wk}$ before expected parturition date. The mean BCS of cows assigned to each of the 3 prepartum diets did not differ among treatments (3.1 \pm 0.4 , mean $\pm \mathrm{SD})$. Prepartum treatment groups were (1) $12 \%$ CP SBM supplement (LSB), (2) 15\% CP SBM supplement (HSB), and (3) 15\% CP SBM supplement plus an animal-marine protein supplement (Prolak; HMP). Diets (Table 2) were formulated to meet NRC (2001) recommendations, except for the higher CP and predicted MP contents of diets 2 and 3. Prepartum diets were formulated to supply an estimated 924, 988 , and $1,111 \mathrm{~g} / \mathrm{d}$ of MP, respectively, at $11.5 \mathrm{~kg}$ of DMI, as calculated by the Cornell-Penn-Miner (CPM) Dairy Nutrition model (Tedeschi et al., 2008). Thus, diets provided MP at near NRC (2001) requirements (LSB), at a level of NRC (2001) plus an allowance for mammary growth (HSB), and at a level greater than requirements (HMP). We retained SBM in the HMP diet at the same inclusion rate as in LSB to ensure that RDP from true protein was similar among diets, while keeping HSB and HMP isonitrogenous.

At parturition, half of the cows in each prepartum group were assigned to 1 of 2 lactation diets: (1) $18 \%$ CP with supplemental protein from SBM (SB), and (2) $18 \% \mathrm{CP}$ with supplemental protein from SBM and the animal-marine protein blend (AMP). Postpartum diets were formulated to supply 2,056 (SB) or 2,293 (AMP) g/d of MP at $21 \mathrm{~kg}$ of DMI. Amount of MP was confounded with the AA composition of the supplemental CP source providing the increased MP (Table 1), but we reasoned that the amount of EAA provided by increasing the amount of MP would have a greater effect on the cows than the small differences of EAA 
in RUP. We provided approximately equal amounts of $\mathrm{SBM}$ and the animal-marine protein blend in an attempt to maintain the ruminal pool of RDP from SBM while increasing predicted MP by $\sim 200 \mathrm{~g} / \mathrm{d}$ and keeping CP similar.

Cows were dried off $60 \mathrm{~d}$ before expected parturition date and maintained on a high-forage far-off dry cow diet. On d -25 before expected parturition, cows were housed in individual tiestall housing and switched to their respective prepartum dietary treatments, which were fed until the time of parturition. After parturition, cows continued to be housed in tiestalls.

Cows were individually fed the prepartum or postpartum diets twice daily (1000 and $1600 \mathrm{~h}$ ) as a TMR. Feed refusals were measured and recorded daily. Feed intakes were measured daily from d -25 through d 63 postpartum. Feeds were sampled weekly, composited by month, and analyzed for contents of DM, ash, CP, $\mathrm{ADF}, \mathrm{NDF}$, and minerals by Cumberland Valley Analytical Services (Hagerstown, MD), using standard wet chemistry methodology (https://www.foragelab.com/ Lab-Services/Forage-and-Feed/Lab-Procedures/).

Cow BW were recorded at weekly intervals. Body condition scores were recorded at 2 -wk intervals by 3 evaluators utilizing the system (scale of $1=$ thin to 5 = obese) developed by Wildman et al. (1982). Previous BCS of each cow was not available to the scorers at time of evaluations.

Cows were milked twice daily (0400 and 1500 h). Milk production was recorded electronically (BouMatic) at each milking and summed to give daily production. Milk samples were collected weekly from 2 consecutive milkings and were composited as a percentage of total milk produced at each milking. Milk was analyzed by infrared analyzer for fat, total protein, SCC, urea N, lactose, and TS by Dairy Lab Services (Dubuque, IA). Yield of $4 \% \mathrm{FCM}$ was calculated using the following equation (Tyrrell and Reid, 1965; adapted from Gaines, 1928):

$$
4 \% \mathrm{FCM}=0.4 \times \text { milk yield }+(15 \times \text { fat yield }) .
$$

Balances of ME, MP, and EAA were calculated using AMTS.Cattle.Pro (version 4.14.3.0, Agricultural Modeling \& Training Systems LLC).

Blood samples were collected 3 times weekly (Tuesday, Thursday, and Saturday) from the coccygeal vein (Dann et al., 2006) into 2 tubes containing heparin that were immediately placed on ice until plasma separation. Plasma was separated by centrifugation at 3,500 $\times g$ for $10 \mathrm{~min}$ at room temperature and subsequently stored frozen $\left(-20^{\circ} \mathrm{C}\right)$ until analysis. Thrice-weekly values were condensed into weekly means for statistical analysis. Glucose was determined by the Trinder reac- tion (kit 315-500; Sigma Chemical Co.). Nonesterified fatty acids (NEFA) were quantified by procedures detailed by Johnson and Peters (1993) using a commercial kit (NEFA-C kit, Wako Chemicals). Urea N (kit 535, Sigma Chemical Co.), BHB (kit 310, Sigma Chemical Co.), and total protein (kit no. 1040901, Roche Laboratories) were analyzed using autoanalyzer techniques. Insulin was analyzed by ${ }^{125}$ I-labeled radioimmunoassay (Coat-A-Count, Diagnostic Products Corporation), using the modifications of Studer et al. (1993).

Liver tissue was sampled by puncture biopsy under local anesthesia (Dann et al., 2006) on d $-25,-10,+1,+$ $10,+21$, and +63 relative to parturition. Samples were frozen in liquid $\mathrm{N}$ before being transferred to freezer storage $\left(-80^{\circ} \mathrm{C}\right)$ until analysis for concentrations of total lipids (Hara and Radin, 1978), triglycerides (Foster and Dunn, 1973), and glycogen (Lo et al., 1970).

On d 63 postpartum, cows received the first injection of GnRH (100 mg, intramuscular, of gonadorelin hydrochloride; $2 \mathrm{~mL}$ of Factrel, Zoetis Animal Health) of the Ovsynch procedure (Pursley et al., 1997). Seven days later (d 70), cows received an injection of $\mathrm{PGF}_{2 \alpha}$, intramuscular. On d 72, cows received the second injection of GnRH. On the day of the last GnRH (d 72), ultrasonography (Aloka 500V, Corometrics Medical Systems Inc.) was used to determine the number and size of follicles on each ovary.

Data from prepartum and postpartum periods were analyzed separately. Statistical computations were performed using the MIXED procedure of SAS (version 9.1, SAS Institute Inc.). Cow was the experimental unit, and no cows were excluded from the final data set. Prepartum data were analyzed as a randomized block design with repeated measures. The model contained effects of prepartum diet and time (week or day) and their interaction as fixed effects, with block and cow as random effects. Postpartum data were analyzed in a $3 \times 2$ factorial arrangement of treatments (3 prepartum diets, 2 postpartum diets) in a randomized complete block design with repeated measures. The model included the factorial combination of prepartum treatment, postpartum treatment, the interaction of prepartum and postpartum treatments, time (week or day), and the 2- and 3-way interactions of time and treatments as fixed effects, with block and cow as random effects. The model for yields of milk and FCM contained the individual cow PTA as a covariate to correct for differences in milk production potential. Covariance structures associated with the repeated effects were modeled with the structure that resulted in the lowest Akaike's information criterion, which was either autoregressive order 1 or autoregressive heterogeneous order 1. Model residuals were assessed for normality and homoscedasticity. Data with studentized residuals 
$\geq|3.5|$ were removed as outliers and the analysis was repeated. Effects of prepartum diets were separated using the Tukey test. Interactions were explored using the SLICE option in SAS. Number of follicles and largest follicle size were evaluated with a Poisson distribution using the GLIMMIX procedure. Significance was declared when $P \leq 0.05$, and trends were evaluated up to $P<0.15$. Significance or trends for interactions are provided as footnotes to the tables. All study data are available upon reasonable request.

\section{RESULTS}

\section{Diets}

Chemical composition of the diets is shown in Table 3. Using the actual DMI, BW, and feed chemical analysis from the study, AMTS.Cattle.Pro predicted that the prepartum diets supplied an estimated $875 \mathrm{~g} / \mathrm{d}$ of MP for LSB, $1,025 \mathrm{~g} / \mathrm{d}$ for HSB, and 1,132 $\mathrm{g} / \mathrm{d}$ for HMP. For the postpartum diets, the amounts of MP estimated were $2,033 \mathrm{~g} / \mathrm{d}$ for SB and 2,121 g/d for AMP. We were successful, therefore, in creating the dietary differences desired, although DMI (and consequently MP predictions) varied from the formulated amounts.

\section{Prepartum Variables}

Prepartum DMI for cows fed LSB, HSB, and HMP were $10.5,11.1$, and $11.0 \mathrm{~kg} / \mathrm{d}$ (Table 4 ), but we observed a trend for interaction of diet and week $(P=$ 0.12; Figure 1). The HSB cows tended to have greater DMI at -1 wk prepartum compared with cows fed LSB or HMP. Prepartum BW and BCS were not affected by dietary treatments (Table 4).

Prepartum concentrations of metabolites in blood are shown in Table 4. Glucose, insulin, NEFA, and BHB did not differ among prepartum diets. An interaction $(P=$ 0.02 ) of prepartum diet by week was detected (Figure $2 \mathrm{~A}$ ) for urea N. All groups had different concentrations at wk -2 , but at wk -1 the plasma concentrations of urea $\mathrm{N}$ for HSB and AMP cows were similar, whereas the urea $\mathrm{N}$ for LSB cows remained lower. An interaction of prepartum diet and week for total protein in plasma showed that total protein was greater $(P=0.01)$ for cows fed HSB than for those fed LSB or HMP at wk -2 but not at wk -1 (Figure 2B).

Prepartum concentrations of total lipids, triglycerides, and glycogen in liver are shown in Table 4. Concentrations of total lipids and triglycerides were not different among treatments. For glycogen, the interaction

Table 3. Chemical analysis of diets for cows fed 1 of 3 diets prepartum and 1 of 2 diets postpartum

\begin{tabular}{|c|c|c|c|c|c|}
\hline \multirow[b]{2}{*}{ Component } & \multicolumn{3}{|c|}{ Prepartum diet ${ }^{1}$} & \multicolumn{2}{|c|}{ Postpartum diet ${ }^{2}$} \\
\hline & LSB & HSB & HMP & SB & AMP \\
\hline$\overline{\mathrm{DM}} \%$ & 52.97 & 52.83 & 52.85 & 61.03 & 61.45 \\
\hline $\mathrm{CP}, \%$ of $\mathrm{DM}$ & 13.30 & 15.94 & 15.57 & 18.07 & 17.58 \\
\hline $\mathrm{MP},{ }^{3} \mathrm{~g} / \mathrm{d}$ & 924 & 988 & 1,111 & 2,056 & 2,293 \\
\hline Neutral detergent insoluble CP, $\%$ of DM & 2.2 & 2.4 & 2.9 & 2.2 & 3.6 \\
\hline Soluble protein, $\%$ of DM & 4.75 & 5.4 & 5.25 & 5.5 & 5.7 \\
\hline Undegradable protein, $\%$ of $\mathrm{CP}$ & 25.1 & 25.9 & 32.6 & 35.4 & 41.4 \\
\hline $\mathrm{NE}_{\mathrm{L}}, \mathrm{Mcal} / \mathrm{kg}$ & 1.56 & 1.58 & 1.60 & 1.67 & 1.67 \\
\hline $\mathrm{NDF}, \%$ of DM & 39.1 & 37.7 & 36.6 & 34.5 & 34.2 \\
\hline $\mathrm{ADF}, \%$ of $\mathrm{DM}$ & 27.6 & 26.1 & 25.6 & 23.4 & 22.9 \\
\hline Fat, \% of DM & 3.5 & 3.7 & 4.1 & 5.1 & 5.0 \\
\hline Starch, \% of DM & 20.4 & 20.5 & 21.0 & 25.2 & 27.1 \\
\hline Ash, \% of DM & 10.6 & 9.9 & 10.1 & 8.7 & 8.3 \\
\hline Lignin, \% of DM & 4.6 & 5.0 & 4.7 & 4.4 & 4.9 \\
\hline NFC, $\%$ of DM & 33.9 & 34.0 & 35.6 & 35.8 & 37.4 \\
\hline $\mathrm{Ca}, \%$ of DM & 1.73 & 1.50 & 1.63 & 1.11 & 1.08 \\
\hline $\mathrm{P}, \%$ of $\mathrm{DM}$ & 0.44 & 0.44 & 0.46 & 0.48 & 0.49 \\
\hline $\mathrm{Mg}, \%$ of $\mathrm{DM}$ & 0.35 & 0.32 & 0.33 & 0.31 & 0.29 \\
\hline $\mathrm{K}, \%$ of $\mathrm{DM}$ & 1.70 & 1.71 & 1.58 & 1.75 & 1.56 \\
\hline $\mathrm{Na}, \%$ of $\mathrm{DM}$ & 0.11 & 0.09 & 0.13 & 0.32 & 0.39 \\
\hline $\mathrm{Fe}, \mathrm{mg} / \mathrm{kg}$ & 715 & 679 & 650 & 571 & 758 \\
\hline $\mathrm{Mn}, \mathrm{mg} / \mathrm{kg}$ & 114 & 100 & 96 & 97 & 99 \\
\hline $\mathrm{Zn}, \mathrm{mg} / \mathrm{kg}$ & 111 & 104 & 119 & 119 & 113 \\
\hline $\mathrm{Cu}, \mathrm{mg} / \mathrm{kg}$ & 23 & 22 & 23 & 24 & 23 \\
\hline DCAD, mEq/100 g of DM & -11.8 & -9.1 & -12.0 & 25.9 & 23.2 \\
\hline
\end{tabular}




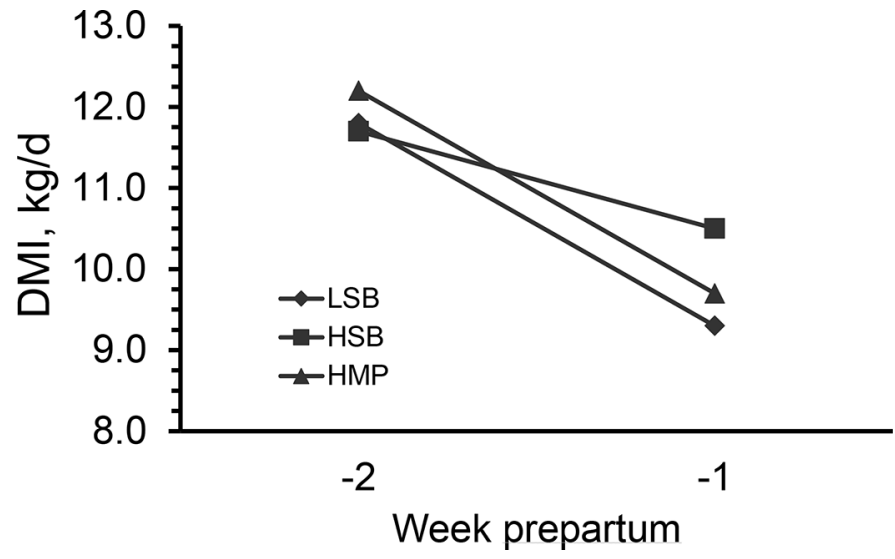

Figure 1. Least squares means for prepartum DMI for cows fed diets containing $12 \%$ CP supplemented with soybean meal (LSB), $15 \%$ CP supplemented with soybean meal (HSB), or $15 \%$ CP supplemented with an animal-marine protein blend (HMP). Prepartum diet $\times$ week, $P=0.12$; average $\mathrm{SEM}=0.8 \mathrm{~kg} / \mathrm{d}$.

of diet and time $(P=0.03)$ showed that cows fed LSB were intermediate to the other treatments at $\mathrm{d}-10$ but then were lowest at d 1 after calving (Figure 2C).

\section{Postpartum Variables}

Postpartum DMI is reported in Table 5. Although overall effects of prepartum diets were not significant, a trend $(P=0.12)$ for a prepartum diet by week ef- fect was detected (data not shown). Groups were at similar DMI at wk 1 after parturition, but HSB cows subsequently did not increase in DMI as rapidly as did the LSB and HMP cows until wk 6; DMI of all groups was similar from wk 6 to 9 . The DMI postpartum did not differ between postpartum diets.

Postpartum BW was not affected by prepartum or postpartum diets (Table 5). A significant prepartum diet by week interaction occurred for postpartum BCS (Figure $3 ; P=0.01$ ). Although $F$-tests for slices at individual weeks were not significant, the cows fed LSB prepartum and SB postpartum (LSB-SB) tended to have the lowest BCS at parturition but had the highest BCS at wk 8, whereas the LSB-AMP cows had the lowest BCS at wk 4 and remained the lowest through wk 8. The SB and AMP groups had similar BCS postpartum. Cows fed AMP postpartum tended $(P=0.12)$ to have a greater decrease of BCS postpartum (Table 5).

Table 5 presents milk yield and milk components. Milk yield was not affected by prepartum diet or postpartum diet. Prepartum treatments did not affect milk fat percentage. Milk fat percentage did not differ $(P=$ 0.24 ) for cows fed SB or AMP postpartum (3.47 and $3.59 \%$, respectively). Main effects for milk fat yield did not differ $(P=0.44)$ among prepartum treatments (Table 5). A prepartum diet by week interaction was detectable for milk fat yields (Figure 4). Slices of the interaction revealed that it occurred primarily at wk 1, where fat yield from cows fed LSB was less than

Table 4. Prepartum variables for cows fed 1 of 3 diets prepartum $(\ln =\log$ normal)

\begin{tabular}{|c|c|c|c|c|c|c|}
\hline \multirow[b]{2}{*}{ Variable } & \multicolumn{3}{|c|}{ Prepartum diet ${ }^{1}$} & \multirow[b]{2}{*}{$\mathrm{SE}$} & \multicolumn{2}{|c|}{$P$-value } \\
\hline & LSB & HSB & HMP & & Diet & Diet $\times$ Week \\
\hline DMI, $\mathrm{kg} / \mathrm{d}$ & 10.5 & 11.1 & 11.0 & 0.7 & 0.80 & 0.12 \\
\hline $\mathrm{BW}, \mathrm{kg}$ & 719 & 752 & 742 & 17 & 0.34 & 0.62 \\
\hline BCS & 2.93 & 3.19 & 3.02 & 0.10 & 0.19 & - \\
\hline \multicolumn{7}{|l|}{ Plasma constituents } \\
\hline Glucose, $\mathrm{mg} / \mathrm{dL}$ & 62.6 & 62.4 & 62.0 & 1.7 & 0.97 & 0.35 \\
\hline Insulin, $\mu \mathrm{U} / \mathrm{mL}$ & 3.1 & 3.6 & 3.8 & 0.9 & 0.82 & 0.57 \\
\hline NEFA, $\ln \mu \mathrm{Eq} / \mathrm{L}$ & 5.40 & 5.29 & 5.35 & 0.09 & 0.72 & 0.06 \\
\hline Back-transformed & 221 & 198 & 211 & - & & \\
\hline $\mathrm{BHB}, \ln \mathrm{mg} / \mathrm{dL}$ & 1.43 & 1.55 & 1.42 & 0.09 & 0.55 & 0.41 \\
\hline Back-transformed & 4.2 & 4.7 & 4.1 & - & & \\
\hline Urea $\mathrm{N}, \mathrm{mg} / \mathrm{dL}$ & 8.9 & 12.2 & 10.9 & 0.48 & $<0.001$ & 0.01 \\
\hline Total protein, $\mathrm{g} / \mathrm{dL}$ & 7.0 & 7.8 & 7.2 & 0.2 & 0.02 & 0.04 \\
\hline \multicolumn{7}{|l|}{ Liver constituents $^{2}$} \\
\hline Total lipid, $\ln \%$ wet wt. & 1.66 & 1.64 & 1.61 & 0.07 & 0.87 & 0.84 \\
\hline Back-transformed & 5.26 & 5.16 & 5.00 & - & & \\
\hline Triglyceride, $\ln \%$ wet wt. & -0.023 & 0.303 & 0.150 & 0.15 & 0.32 & 0.40 \\
\hline Back-transformed & 0.98 & 1.35 & 1.16 & - & & \\
\hline Glycogen, $\ln \%$ wet wt. & $0.31^{\mathrm{b}}$ & $0.76^{\mathrm{a}}$ & $0.48^{\mathrm{ab}}$ & 0.10 & 0.01 & 0.03 \\
\hline Back-transformed & 1.36 & 2.14 & 1.62 & - & & \\
\hline
\end{tabular}

${ }^{a-c}$ Least squares means within a row not sharing a common superscript differ $(P<0.05)$.

${ }^{1} \mathrm{LSB}=$ low soybean meal; HSB = high soybean meal; HMP = high animal-marine protein.

${ }^{2}$ Means of concentrations (wet weight basis) from biopsies at $\mathrm{d}-10$ and +1 , corrected for pretreatment measures at $\mathrm{d}-25$. 

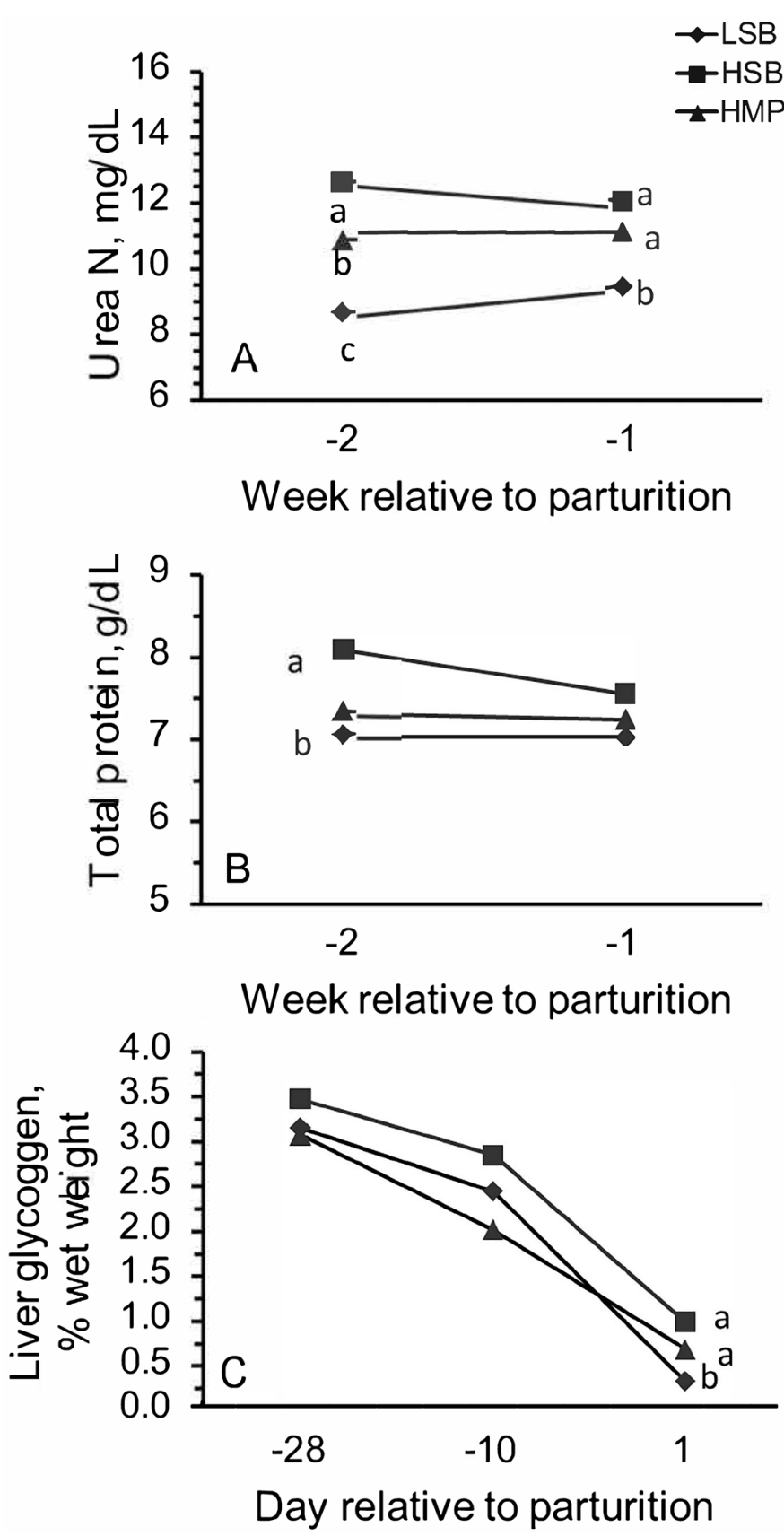

Figure 2. Least squares means for concentration of plasma urea $\mathrm{N}$ (A), plasma total protein (B), and liver glycogen (C) in plasma from cows fed prepartum diets containing $12 \% \mathrm{CP}$ supplemented with soybean meal (LSB), $15 \%$ CP supplemented with soybean meal (HSB), or $15 \% \mathrm{CP}$ supplemented with an animal-marine protein blend (HMP). A: Prepartum diet $\times$ week, $P=0.01$; average SEM $=0.51 \mathrm{mg} / \mathrm{dL}$. B: Prepartum diet $\times$ week, $P=0.04$; average $S E M=0.24 \mathrm{~g} / \mathrm{dL}$. C: Prepartum diet $\times$ week, $P=0.03$; average SEM for log normaltransformed values $=0.2 \%$ of wet weight. Letters on means for a week denote significant difference at that time $(P<0.05)$.

those fed either HSB or HMP. Because cows fed AMP postpartum produced numerically more milk with a numerically higher milk fat content, milk fat yield tended
$(P=0.12)$ to be greater for cows fed AMP than for those fed SB (1.27 vs. $1.20 \mathrm{~kg} / \mathrm{d}$, respectively).

No main effects of prepartum diet were detected for $4 \%$ FCM (Table 5 ). The prepartum diet by week effect was significant $(P=0.05)$ for FCM (data not shown). Similar to results for fat yield, the LSB cows had the lowest FCM yield at wk 1 but were similar to the other groups at other weeks. The FCM yields did not differ $(P=0.19)$ between postpartum diets (33.6 vs. 32.2 $\mathrm{kg} / \mathrm{d}$ for AMP and SB, respectively). No prepartum or postpartum diet effects were detected for milk total protein content or yield, and the prepartum by postpartum interaction was not significant.

Apparent gross efficiency, calculated as 4\% FCM/ DMI, is shown in Table 5. A prepartum diet by postpartum diet by week interaction occurred (Figure 5; $P<0.001)$. The slice analysis showed that significant differences occurred at wk 1 and 2 . At wk 1 , treatments HSB-AMP or HMP-SB differed from each other and from all other treatment combinations. At wk 2, cows fed HSB-AMP differed from those fed all other treatment combinations. Overall, cows fed AMP postpartum showed greater gross efficiency than did the SB cows (1.82 vs. 1 . 68 , respectively; $P=0.03$ ).

Milk urea $\mathrm{N}$ concentrations are shown in Table 5 . Prepartum diets had no main effects on MUN. Cows fed SB or AMP postpartum had similar values (12.5 and $11.9 \mathrm{mg} / \mathrm{dL}$, respectively; $P=0.25$ ).

Table 6 presents calculated balances of ME and MP, as well as calculated EAA balances relative to requirements. Prepartum, ME balance was slightly negative for LSB but positive for HSB and HMP. Balance of MP was negative for LSB and HSB but positive for HMP. Postpartum, all treatments were in negative ME balance and MP balance, but AMP was less negative in MP balance than SB.

Table 7 shows postpartum metabolites in plasma. For plasma glucose, the prepartum diet by postpartum diet interaction $(P=0.04)$ was significant; means were 58.6, $56.4,55.9,60.1,59.6$, and 55.2 for LSB-SB, LSB-AMP, HS-SB, HSB-AMP, HMP-SB, and HMP-AMP, respectively. Means for HSB-AMP and HMP-AMP differed significantly from one another.

Postpartum insulin concentrations did not differ among prepartum diets or between postpartum diets (Table 7$)$. A prepartum diet by week interaction $(P=$ 0.05 ) was detected (Figure 6A). The slice test detected differences at wk 1,5 , and 6 . Results were variable, and the pattern of response is difficult to interpret, but cows fed HMP were high immediately after calving compared with other treatments. Cows fed HSB were low after calving and increased at wk 3 , whereas cows fed LSB were intermediate after calving and remained relatively low throughout the study. 
Plasma NEFA (Table 7) was affected by a prepartum diet by week interaction (Figure 6B). The slice test showed that NEFA were higher at wk 3 for cows fed HSB or HMP prepartum than for those fed LSB. Cows fed AMP postpartum had greater $(P=0.02)$ NEFA concentrations than cows fed SB postpartum (backtransformed means 245 vs. $198 \mu \mathrm{eq} / \mathrm{L}$, respectively). Plasma BHB was not affected by prepartum diets. Cows fed AMP postpartum had a significantly greater BHB concentration compared with cows fed SB (backtransformed means 5.3 vs. $4.5 \mathrm{mg} / \mathrm{dL}$, respectively; $P$ $=0.04)$.

We detected a trend $(P=0.08)$ for a prepartum diet by postpartum diet by week interaction for plasma urea $\mathrm{N}$ (Figure $6 \mathrm{C}$ ). Slices had significant $F$-tests at wk 3, $4,5,6,7$, and 9 , generally showing that cows fed SB postpartum had greater urea $\mathrm{N}$ than those fed AMP. Plasma urea $\mathrm{N}$ was greater $(P=0.001)$ in the cows fed SB postpartum compared with those fed AMP (14.4 vs. $12.5 \mathrm{mg} / \mathrm{dL}$, respectively; Table 5).

Prepartum diet tended $(P=0.08)$ to affect plasma total protein concentration, with cows fed HSB greater than those fed LSB and HMP intermediate (Table 7). Cows fed AMP postpartum had greater $(P=0.03)$ total protein concentrations than cows fed SB (8.2 vs. 7.6 $\mathrm{g} / \mathrm{dL}$, respectively).

Postpartum concentrations of total lipids, triglycerides, and glycogen in liver are shown in Table 7. No prepartum diet effects were significant. Total lipid percentages did not differ significantly for cows fed SB or AMP postpartum (back-transformed means 5.6 vs. $5.9 \%$, respectively; $P=0.63$ ). Triglyceride concentrations were slightly higher for cows fed AMP postpartum (back-transformed means 1.2 vs. $0.9 \%$ ), but the difference was not significant $(P=0.18)$. Glycogen content was greater $(P=0.03)$ for cows fed SB postpartum than for those fed AMP postpartum.

Table 8 lists the health disorders experienced by cows fed the prepartum diets. No statistical analysis was performed, and numbers are limited, so caution should be exercised in interpretation. Only LSB cows had milk fever cases. Cows fed HMP had the fewest retained placentas compared with cows fed LSB or $\operatorname{HSB}(1,4$, and 6 , respectively; Table 8$)$. The displaced abomasums occurred between 1 and 4 wk postpartum.

Cows in LSB had a smaller number of ovarian follicles of 6 to $9 \mathrm{~mm}$ in diameter than cows in HSB and HMP (Table 9 ). Cows fed SB postpartum tended $(P=$ 0.12 ) to have a greater number of follicles than cows fed AMP. We detected no treatment effects on the number of follicles $>10 \mathrm{~mm}$. The size of the largest follicle was greater $(P=0.01)$ for cows fed LSB or HMP prepartum than for those fed HSB.

\section{DISCUSSION}

\section{Prepartum Variables}

The DMI for cows fed LSB prepartum was lower than for cows fed HSB or HMP. The decrease might be due

Table 5. Postpartum DMI, BW, BCS, milk yield, and milk components for cows fed 1 of 3 diets prepartum (Pre) and 1 of 2 diets postpartum (Post)

\begin{tabular}{|c|c|c|c|c|c|c|c|c|c|}
\hline \multirow[b]{2}{*}{ Variable } & \multicolumn{3}{|c|}{ Prepartum diet ${ }^{1}$} & \multicolumn{2}{|c|}{ Postpartum diet ${ }^{2}$} & \multirow[b]{2}{*}{ SE } & \multicolumn{3}{|c|}{$P$-value } \\
\hline & LSB & HSB & HMP & $\mathrm{SB}$ & $\mathrm{AMP}$ & & Pre & Post & Pre $\times$ Post \\
\hline $\mathrm{BW}, \mathrm{kg}$ & 616 & 636 & 627 & 635 & 617 & 18 & 0.56 & 0.21 & 0.26 \\
\hline $\mathrm{BCS}^{\mathrm{a}}$ & 2.38 & 2.56 & 2.45 & 2.48 & 2.44 & 0.12 & 0.54 & 0.71 & 0.88 \\
\hline${\text { BCS } \text { change }^{3}}$ & -0.92 & -1.03 & -0.92 & -0.88 & -1.03 & 0.12 & 0.59 & 0.12 & 0.19 \\
\hline Milk yield, $\mathrm{kg} / \mathrm{d}$ & 35.6 & 35.7 & 36.1 & 35.2 & 36.4 & 2.1 & 0.94 & 0.37 & 0.18 \\
\hline $4 \% \mathrm{FCM}^{4, \mathrm{~b}} \mathrm{~kg} / \mathrm{d}$ & 32.7 & 33.5 & 32.6 & 32.2 & 33.6 & 1.8 & 0.77 & 0.19 & 0.21 \\
\hline Milk protein, \% & 2.98 & 3.05 & 2.92 & 2.98 & 2.99 & 0.07 & 0.18 & 0.86 & 0.27 \\
\hline Milk protein yield, kg/d & 1.04 & 1.08 & 1.05 & 1.04 & 1.07 & 0.06 & 0.69 & 0.45 & 0.36 \\
\hline Efficiency $^{5 a}$ & 1.70 & 1.82 & 1.73 & 1.68 & 1.82 & 0.07 & 0.27 & 0.03 & 0.50 \\
\hline Milk urea $\mathrm{N}, \mathrm{mg} / \mathrm{dL}$ & 12.7 & 12.1 & 11.8 & 12.5 & 11.9 & 0.5 & 0.36 & 0.25 & 0.63 \\
\hline
\end{tabular}

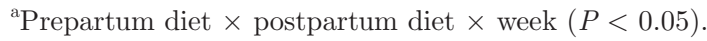

${ }^{\mathrm{b}}$ Prepartum diet $\times$ week $(P<0.05)$.

${ }^{1} \mathrm{LSB}=$ low soybean meal; HSB $=$ high soybean meal; HMP $=$ high animal-marine protein.

${ }^{2} \mathrm{SB}=$ soybean meal; AMP = animal-marine protein.

${ }^{3}$ Last score prepartum minus nadir postpartum.

${ }^{4}$ Calculated as $(0.4 \times \mathrm{kg}$ milk $)+(15 \times \mathrm{kg}$ milk fat $)$.

${ }^{5}$ Calculated as FCM/DMI.
} 


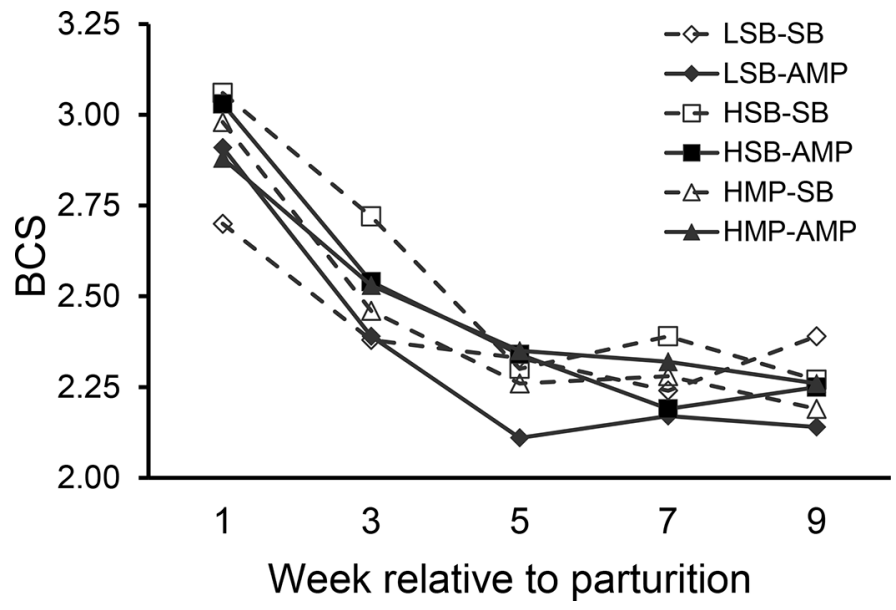

Figure 3. Least squares means for postpartum BCS for cows fed a prepartum diet containing $12 \% \mathrm{CP}$ supplemented with soybean meal and postpartum diet supplemented with soybean meal (LSB-SB), prepartum diet containing $12 \% \mathrm{CP}$ supplemented with soybean meal and postpartum diet supplemented with an animal-marine protein blend (LSB-AMP), prepartum diet containing 15\% CP supplemented with soybean meal and postpartum diet supplemented with soybean meal (HSB-SB), prepartum diet containing 15\% CP supplemented with soybean meal and postpartum diet supplemented with animal-marine protein blend (HSB-AMP), prepartum diet containing 15\% CP supplemented with an animal-marine protein blend and postpartum diet supplemented with soybean meal (HMP-SB), or prepartum diet containing $15 \% \mathrm{CP}$ supplemented with an animal-marine protein blend and postpartum diet supplemented with animal-marine protein blend (HMP-AMP). Prepartum diet $\times$ postpartum diet $\times$ week, $P=0.01$; average SEM $=0.14$ unit. At wk 1 LSB-SB differed from HSB-SB $(P$ $=0.08)$. At wk 3 , HSB-SB differed from LSB-SB and LSB-AMP $(P$ $<0.10)$.

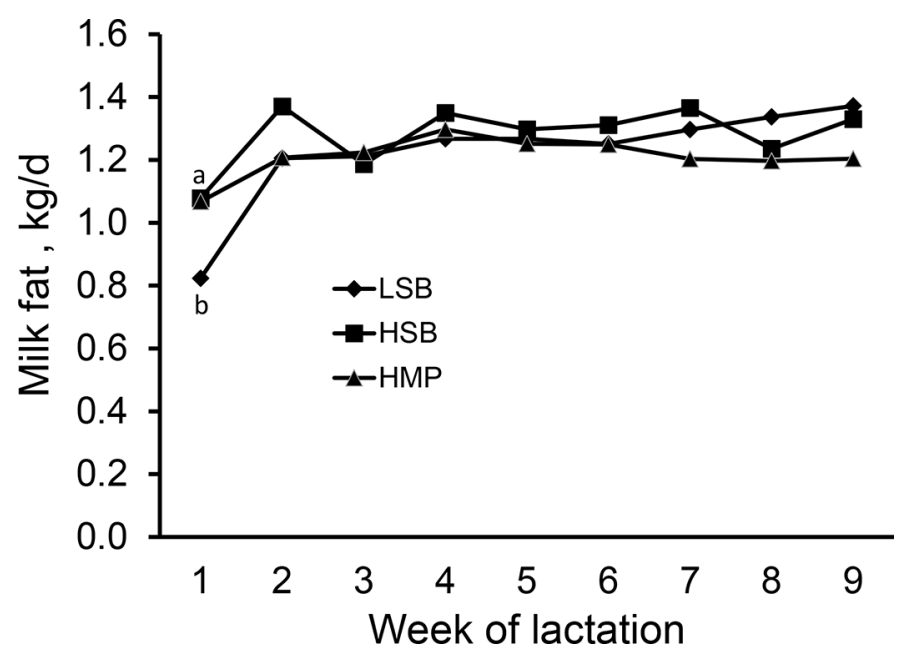

Figure 4. Least squares means for milk fat yield $(\mathrm{kg} / \mathrm{d})$ for cows fed a prepartum diet containing $12 \% \mathrm{CP}$ supplemented with soybean meal (LSB), prepartum diet containing 15\% CP supplemented with soybean meal (HSB), and prepartum diet containing 15\% CP supplemented with an animal-marine protein blend (HMP). Prepartum diet $\times$ week, $P=0.01$; average SEM $=0.08 \mathrm{~kg} /$ d. Letters on means for a week denote significant difference at that time $(P=0.01)$. to an RDP limitation for optimal rumen fiber digestion, as calculated RDP was $9.3 \%$ of DM in LSB. However, research by Putnam and Varga (1998) demonstrated that dry cows consumed diets as low as $10.6 \% \mathrm{CP}$ without any adverse effects on DMI. In that study, cows consuming prepartum diets containing from 10.6 to $14.5 \% \mathrm{CP}$ did not differ in DMI, and RDP (not reported) would have been lower than in our study. Huyler et al. (1999) also measured similar DMI among groups with prepartum diets containing 11.7, 15.6, and $20.6 \%$ CP. Decreasing glycogen corresponded to the decline in DMI during the prepartum period and likely reflects the increasing negative energy balance as cows approached and underwent calving.

Prepartum BW and BCS were similar among groups of cows fed the different diets. Several studies using multiparous cows have reported no effects on BW or BCS (Moorby et al., 1996; Huyler et al., 1999; Greenfield et al., 2000) when cows were fed different dietary

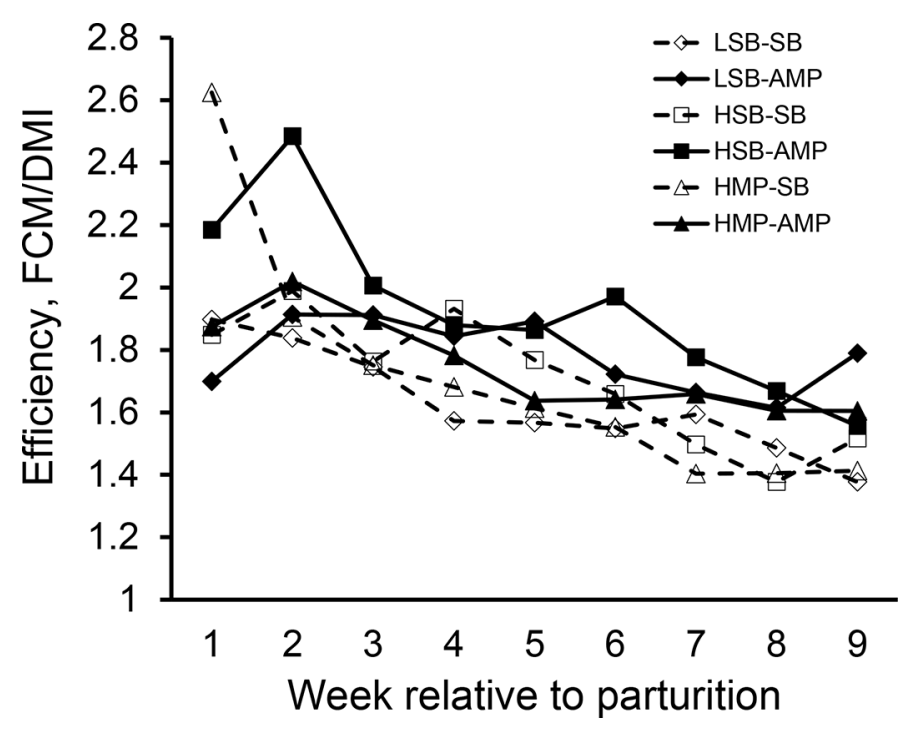

Figure 5. Least squares means for efficiency (FCM/DMI) for cows fed prepartum diets containing $12 \%$ CP supplemented with soybean meal and postpartum diet supplemented with soybean meal (LSB-SB), prepartum diet containing $12 \% \mathrm{CP}$ supplemented with soybean meal and postpartum diet supplemented with an animal-marine protein blend (LSB-AMP), prepartum diet containing 15\% CP supplemented with soybean meal and postpartum diet supplemented with soybean meal (HSB-SB), prepartum diet containing 15\% CP supplemented with soybean meal and postpartum diet supplemented with animalmarine protein blend (HSB-AMP), prepartum diet containing 15\% $\mathrm{CP}$ supplemented with an animal-marine protein blend and postpartum diet supplemented with soybean meal (HMP-SB), or prepartum diet containing $15 \% \mathrm{CP}$ supplemented with an animal-marine protein blend and postpartum diet supplemented with animal-marine protein blend (HMP-AMP). Prepartum diet $\times$ postpartum diet $\times$ week, $P<$ 0.001 ; average $\mathrm{SEM}=0.16 \mathrm{~kg} / \mathrm{kg}$. At wk 1 , treatments HSB-AMP or HMP-SB differed from each other and from all other treatment combinations. At wk 2, cows fed HSB-AMP differed from those fed all other treatment combinations. 
Table 6. Calculated intakes, requirements, and balance of ME and MP, and predicted supply of EAA relative to requirements ${ }^{1}$

\begin{tabular}{|c|c|c|c|c|c|}
\hline \multirow[b]{2}{*}{ Item } & \multicolumn{3}{|c|}{ Prepartum diet ${ }^{2}$} & \multicolumn{2}{|c|}{ Postpartum diet ${ }^{3}$} \\
\hline & LSB & HSB & HMP & $\mathrm{SB}$ & $\mathrm{AMP}$ \\
\hline Prepartum ME intake, Mcal/d & 24.6 & 26.3 & 26.3 & - & - \\
\hline Prepartum ME required, $\mathrm{Mcal} / \mathrm{d}$ & 25.0 & 25.7 & 25.4 & - & - \\
\hline Prepartum ME balance, Mcal/d & -0.3 & 0.6 & 0.9 & - & - \\
\hline Prepartum MP intake, $\mathrm{g} / \mathrm{d}$ & 842 & 950 & 1,057 & - & - \\
\hline Prepartum MP required, $\mathrm{g} / \mathrm{d}$ & 986 & 1,009 & 998 & - & - \\
\hline Prepartum MP balance, $\mathrm{g} / \mathrm{d}$ & -143 & -59 & 58 & - & - \\
\hline Postpartum ME intake, Mcal/d & 52.0 & 49.0 & 52.8 & 52.3 & 49.9 \\
\hline Postpartum ME required, Mcal/d & 58.5 & 58.4 & 57.9 & 57.6 & 59.0 \\
\hline Postpartum ME balance, Mcal/d & -6.5 & -9.3 & -5.1 & -5.4 & -9.1 \\
\hline Postpartum MP intake, $\mathrm{g} / \mathrm{d}$ & 2,130 & 1,971 & 2,162 & 2,033 & 2,121 \\
\hline Postpartum MP required, $\mathrm{g} / \mathrm{d}$ & 2,456 & 2,426 & 2,447 & 2,448 & 2,454 \\
\hline Postpartum MP balance, g/d & -325 & -455 & -285 & -415 & -333 \\
\hline Postpartum Lys supply, \% required & 80 & 76 & 82 & 78 & 80 \\
\hline Postpartum Met supply, \% required & 74 & 69 & 75 & 71 & 73 \\
\hline Postpartum His supply, \% required & 100 & 94 & 102 & 92 & 103 \\
\hline Postpartum Leu supply, \% required & 74 & 69 & 75 & 70 & 75 \\
\hline Postpartum Thr supply, \% required & 105 & 99 & 107 & 101 & 105 \\
\hline Postpartum Arg supply, \% required & 106 & 101 & 107 & 103 & 104 \\
\hline Postpartum Ile supply, \% required & 85 & 79 & 87 & 85 & 82 \\
\hline Postpartum Val supply, \% required & 90 & 84 & 91 & 83 & 91 \\
\hline Postpartum Phe supply, $\%$ required & 85 & 79 & 87 & 81 & 85 \\
\hline Postpartum Trp supply, \% required & 82 & 77 & 84 & 81 & 80 \\
\hline
\end{tabular}

${ }^{1}$ Calculated from treatment means using AMTS.Cattle.Pro model (version 4.14.3.0, Agricultural Modeling \& Training Systems LLC).

${ }^{2} \mathrm{LSB}=$ low soybean meal; HSB $=$ high soybean meal; HMP $=$ high animal-marine protein.

${ }^{3} \mathrm{SB}=$ soybean meal; AMP = animal-marine protein.

Table 7. Postpartum concentrations of compounds in plasma and liver for cows fed 1 of 3 diets prepartum (Pre) and 1 of 2 diets postpartum (Post; $\ln =\log$ normal)

\begin{tabular}{|c|c|c|c|c|c|c|c|c|c|}
\hline \multirow[b]{2}{*}{ Variable } & \multicolumn{3}{|c|}{ Prepartum diet ${ }^{1}$} & \multicolumn{2}{|c|}{ Postpartum diet ${ }^{2}$} & \multirow[b]{2}{*}{$\mathrm{SE}$} & \multicolumn{3}{|c|}{$P$-value } \\
\hline & LSB & HSB & HMP & $\mathrm{SB}$ & AMP & & Pre & Post & Pre $\times$ Post \\
\hline Glucose, mg/dL & 57.4 & 57.9 & 57.4 & 58.0 & 57.2 & 1.8 & 0.94 & 0.58 & 0.04 \\
\hline Insulin, ${ }^{a} \ln \mu \mathrm{IU} / \mathrm{mL}$ & 0.21 & 0.33 & 0.42 & 0.26 & 0.38 & 0.20 & 0.55 & 0.44 & 0.62 \\
\hline Back-transformed & 1.23 & 1.39 & 1.53 & 1.30 & 1.46 & - & & & \\
\hline $\mathrm{NEFA},{ }^{\mathrm{a}} \ln \mu \mathrm{Eq} / \mathrm{L}$ & 5.34 & 5.49 & 5.34 & 5.29 & 5.50 & 0.11 & 0.28 & 0.02 & 0.84 \\
\hline Back-transformed & 4.8 & 5.0 & 5.0 & 4.5 & 5.3 & - & & & \\
\hline Urea $\mathrm{N},{ }^{\mathrm{b}} \mathrm{mg} / \mathrm{dL}$ & 13.6 & 13.1 & 13.5 & 14.4 & 12.5 & 0.75 & 0.73 & 0.001 & 0.24 \\
\hline Total protein, g/dL & $7.5^{\mathrm{y}}$ & $8.2^{\mathrm{x}}$ & $8.0^{\mathrm{xy}}$ & 7.6 & 8.2 & 0.3 & 0.08 & 0.02 & 0.62 \\
\hline \multicolumn{10}{|l|}{ Liver $^{3}$} \\
\hline Total lipid, ln \% & 1.70 & 1.81 & 1.73 & 1.73 & 1.77 & 0.09 & 0.47 & 0.63 & 0.41 \\
\hline Back-transformed & 5.5 & 6.1 & 5.6 & 5.6 & 5.9 & - & & & \\
\hline Triglyceride, $\ln \%$ & 0.0049 & -0.0632 & 0.0616 & -0.150 & 0.143 & 0.25 & 0.89 & 0.18 & 0.70 \\
\hline
\end{tabular}

${ }^{\text {a }}$ Prepartum diet $\times$ week $(P<0.05)$.

${ }^{\mathrm{b}}$ Prepartum diet $\times$ postpartum diet $\times$ week $(P<0.10)$.

${ }^{\mathrm{x}, \mathrm{y}}$ Means without a common superscript differ $(P<0.10)$.

${ }^{1} \mathrm{LSB}=$ low soybean meal; HSB $=$ high soybean meal; HMP $=$ high animal-marine protein.

${ }^{2} \mathrm{SB}=$ soybean meal; AMP = animal-marine protein.

${ }^{3}$ Means of concentrations (wet weight basis) from biopsies on d 10, 21, and 63 postpartum. 

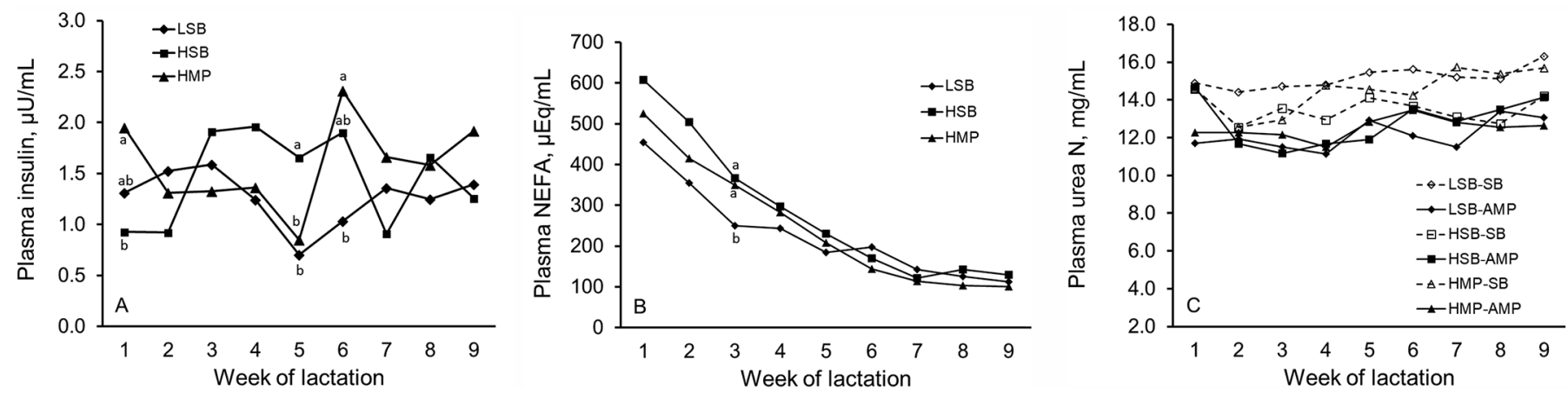

Figure 6. Least squares means for plasma concentrations of insulin (A), nonesterified fatty acids (NEFA, B), and urea N (C) in cows fed different diets prepartum and postpartum. Letters on means for a week denote significant difference at that time $(P<0.05)$. A: Back-transformed means for plasma insulin in cows fed a prepartum diet containing $12 \% \mathrm{CP}$ supplemented with soybean meal (LSB), prepartum diet containing $15 \%$ CP supplemented with soybean meal (HSB), or prepartum diet containing $15 \%$ CP supplemented with soybean meal and animal-marine protein blend (HMP). Prepartum diet $\times$ week interaction, $P=0.02$; average SEM of log normal (ln)-transformed data $=0.25 \mu \mathrm{U} / \mathrm{mL}$. B: Backtransformed means for plasma NEFA from cows fed a prepartum diet containing $12 \%$ CP supplemented with soybean meal (LSB), prepartum diet containing 15\% CP supplemented with soybean meal (HSB), or prepartum diet containing $15 \%$ CP supplemented with soybean meal and an animal-marine protein blend (HMP). Prepartum diet $\times$ week, $P=0.005$; average SEM of ln-transformed values $=0.13 \mu \mathrm{Eq} / \mathrm{mL}$. C: Least squares means for plasma urea $\mathrm{N}$ from cows fed prepartum diets containing $12 \% \mathrm{CP}$ supplemented with soybean meal and postpartum diet supplemented with soybean meal (LSB-SB), prepartum diet containing $12 \%$ CP supplemented with soybean meal and postpartum diet supplemented with an animal-marine protein blend (LSB-AMP), prepartum diet containing 15\% CP supplemented with soybean meal and postpartum diet supplemented with soybean meal (HSB-SB), prepartum diet containing $15 \%$ CP supplemented with soybean meal and postpartum diet supplemented with animal-marine protein blend (HSB-AMP), prepartum diet containing 15\% CP supplemented with an animal-marine protein blend and postpartum diet supplemented with soybean meal (HMP-SB), or prepartum diet containing $15 \%$ CP supplemented with an animalmarine protein blend and postpartum diet supplemented with animal-marine protein blend (HMP-AMP). Prepartum diet $\times$ postpartum diet $\times$ week interaction, $P=0.05$; average $\mathrm{SEM}=1.0 \mathrm{mg} / \mathrm{dL}$. Significant differences occurred at wk 2, 3, 4, 5, 6, 7, and 9 .

concentrations of CP or RUP. Energy differences in prepartum diets for multiparous cows have more influence on BW and BCS responses than dietary protein differences (Mashek and Beede, 2001). The greater ME and MP balances for cows fed HSB and HMP could have provided more $\mathrm{ME}$ and MP to the immune system, but this was not measured in our experiment.

Results for plasma urea $\mathrm{N}$ reflect the differences in RDP supplied across diets, with HSB having the greatest and LSB the least. Increased concentration of total protein in plasma of cows fed HSB suggests improved protein status, but the lower urea $\mathrm{N}$ for cows fed HMP indicates that $\mathrm{N}$ use in those cows may have been more efficient.

\section{Postpartum Variables}

Increased prepartum MP supply for cows fed HSB or HMP tended to increase milk fat yield and 4\% FCM yield during wk 1 postpartum compared with cows fed LSB. Other measures of production were not affected by prepartum diets. The overall lack of increased milk yield in response to increasing MP contents of prepartum diets for multiparous cows above NRC (2001) recommendations has been extensively documented (Husnain and Santos, 2019). Although our cows were all multiparous, primiparous cows have a higher prepartum requirement for MP and benefit from diets providing larger amounts of MP prepartum (Husnain and Santos, 2019).

The general lack of response of milk protein yields to different sources of CP in the prepartum diet has been demonstrated previously. Huyler et al. (1999) found no response in milk protein yield after feeding different concentrations of dietary CP and RUP to prepartum cows. Doepel et al. (2002) also did not detect improved milk protein yield from cows fed different concentrations of dietary CP. Our results agree with their conclusions. The lack of effect of prepartum MP supply on milk protein contradicts our hypothesis and runs contrary to some other studies in which increased prepartum MP increased milk protein content or yield (Zhang et al., 2015; Amanlou et al., 2017; Carder and Weiss, 2017).

Table 8 . Health disorders for cows fed 1 of 3 diets prepartum ${ }^{1}$

\begin{tabular}{lccc}
\hline & \multicolumn{3}{c}{ Prepartum diet $^{2}$} \\
\cline { 2 - 4 } Variable & LSB & HSB & HMP \\
\hline Milk fever & 2 & 0 & 0 \\
Retained placenta & 4 & 6 & 1 \\
Displaced abomasum & 0 & 1 & 1 \\
Ketosis & 2 & 4 & 3 \\
\hline
\end{tabular}

${ }^{1} \mathrm{n}=20$ per diet.

${ }^{2} \mathrm{LSB}=$ low soybean meal; HSB $=$ high soybean meal; HMP $=$ animalmarine protein. 
Table 9. Poisson regression for number and size of follicles on d 72 postpartum for cows fed 1 of 3 diets prepartum (Pre) and 1 of 2 diets postpartum (Post) throughout the experimental period

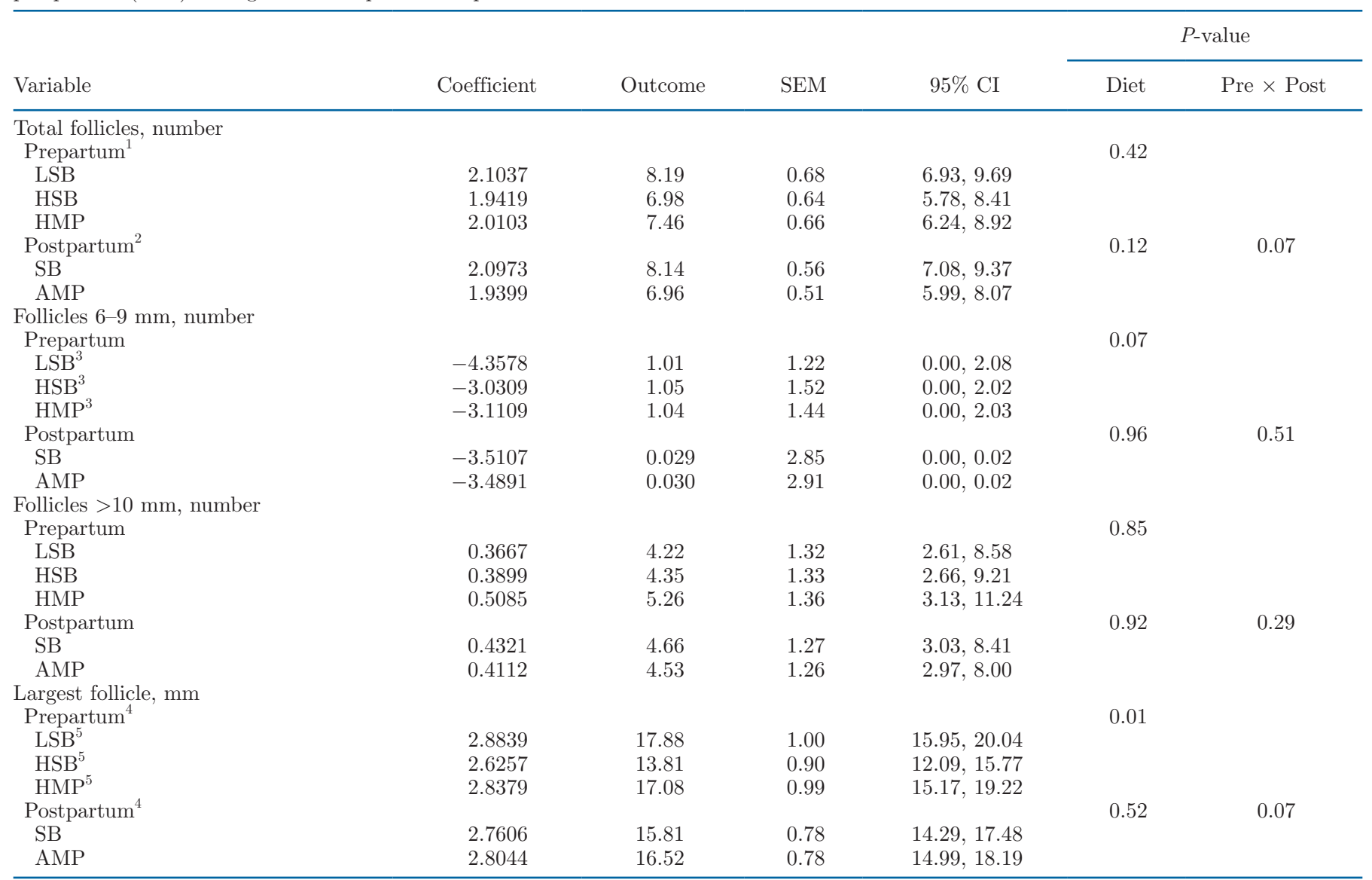

${ }^{1} \mathrm{LSB}=$ low soybean meal; HSB $=$ high soybean meal; HMP = animal-marine protein.

${ }^{2} \mathrm{SB}=$ soybean meal; AMP = animal-marine protein.

${ }^{3}$ LSB vs. HSB, $P=0.026$; LSB vs. AMP, $P=0.043 ; \mathrm{HSB}$ vs. AMP, $P=0.855$.

${ }^{4}$ Prepartum by postpartum diet interaction, $P=0.020$; LSB and SB vs. HSB and AMP, $P=0.017 ;$ LSB and AMP vs. HSB and AMP, $P=$ $0.001 ; \mathrm{HSB}$ and AMP vs. AMP and AMP, $P=0.002$.

${ }^{5}$ LSB vs. HSB, $P=0.0048$; LSB vs. AMP, $P=0.573$; HSB vs. AMP, $P=0.020$.

The meta-analysis by Husnain and Santos (2019) found that increased prepartum MP increased milk protein only in multiparous cows producing $>36 \mathrm{~kg}$ of milk daily.

The difference in MP between SB and AMP diets postpartum was not as large as formulated because of the nonsignificantly lower DMI for cows fed AMP, thus limiting predicted microbial protein synthesis and intake of RUP. Another study with the same protein source as AMP (Prolak) observed no effect on DMI (Santos et al., 1999), but some herds in a multi-herd study in which Prolak was introduced on farms reported decreased DMI (Ferguson et al., 2000). In addition, some studies have shown that fish meal or blood meal (components of Prolak) decreased DMI (Santos et al., 1998). Cows fed AMP postpartum tended to have a greater decrease of BCS postpartum, likely related to the numerically lower DMI with numerically greater milk production and the corresponding increase in negative energy balance. The lack of significant milk production response to the greater MP supply postpartum also might be a result of the numerically lower DMI for cows fed AMP and the fact that cows were still in negative MP balance. The difference in milk yield $(1.2 \mathrm{~kg} / \mathrm{d})$ between cows fed SB or AMP postpartum (35.2 and $36.4 \mathrm{~kg} / \mathrm{d}$, respectively) was not significant but is similar to the mean increase $(1.24 \mathrm{~kg} / \mathrm{d})$ of milk from 35 farms when Prolak was fed (Ferguson et al., 2000). Future studies should pay attention to 2 factors: the possible effects of this source of MP on DMI and the response to improved MP balance while keeping ME balance unaltered.

Results from studies determining milk protein response to different postpartum protein sources have 
been mixed. Some have found positive responses to animal-marine protein supplementation on milk protein yield (Chan et al., 1997; Santos et al., 1999), but others have not (Wattiaux et al., 1994; Johnson-VanWieringen et al., 2007). Lines and Weiss (1996) fed animal protein supplements to meet $100 \%$ of recommendations for RUP, or a diet containing ammoniated hay, urea, and soybean meal that met only $70 \%$ of recommendations for RUP; milk composition was unaffected by diet. Where no positive response was detected, the control diets may have supplied adequate MP and AA for milk protein synthesis, or the added RUP sources may have decreased microbial CP synthesis (Clark et al., 1992; Santos et al., 1998). Differences in the resulting ME balance also could have negated effects of improved MP balance.

Postpartum supplementation of AMP resulted in improved gross efficiency of FCM production. Efficiencies calculated in this manner (FCM/DMI) are subject to inflation by the contribution of mobilized body stores in early lactation. Using the mean results from our study, correcting for the greater mobilization of body reserves for milk production (Table 5) using the methodology described in NRC (2001) yielded net efficiencies for AMP and SB of 1.70 and 1.58, respectively. These findings indicate that diet during early lactation was the major driver of improved efficiency, rather than increased body fat mobilization. Reasons might be a more favorable balance of metabolizable AA to available energy or an improved metabolizable AA profile reaching the intestine (NRC, 2001). Estimations from our data suggest that AMP improved the relative supplies of Lys, Met, Leu, His, Val, and Phe compared with SB. Greater negative energy balance might have compromised the responses to the improved EAA balance.

The greater NEFA concentration in cows fed AMP agrees with the numerically lower DMI and increased BCS loss incurred by the cows fed AMP. The increased NEFA concentrations for cows fed AMP may have contributed to the numerically increased $4 \% \mathrm{FCM}$ and milk fat yields, with more preformed fatty acids available in blood for uptake by the mammary gland. Although concentrations were not high, the greater plasma BHB and slightly higher concentration of triglyceride in liver for cows fed AMP reflect the increased BCS loss and higher NEFA concentrations of the AMP group as an adaptive response to negative energy balance. Greater glycogen postpartum for SB cows may be a result of the improved energy balance relative to AMP.

Ørskov et al. (1977) found that postruminal supplementation of protein in cows during negative energy balance increased milk production and increased body fat mobilization. Responses documented by Larsen et al. (2014) to postruminal infusion of protein confirm those findings. Cadórniga and López Diaz (1995) fed a higher-protein diet and reported that responsiveness of adipose tissue to catecholamine stimulation was increased. Although the increased NEFA and BCS loss in cows fed AMP in our study is confounded by the nonsignificant decrease in DMI, it would be of interest to determine the response of cows fed AMP to catecholamine challenges.

The greater plasma urea $\mathrm{N}$ indicates that cows fed SB likely had more RDP breakdown in the rumen than the ruminal microbes could utilize for microbial protein synthesis, compared with the AMP cows, with the resultant excess production of ammonia converted to urea. The higher concentration of total protein in cows fed AMP reflects their higher dietary MP, similar to results of Larsen et al. (2014). Together these results indicate that greater MP supply postpartum led to an improvement in body protein status.

Cows in LSB had a smaller number of follicles of 6 to $9 \mathrm{~mm}$ in diameter than cows in HSB and HMP (Table 8). Differences were small, and, given our small sample size, more research is justified, especially using factorial designs testing prepartum and postpartum dietary effects. Differences in MP balance could have influenced follicle size, but literature support is lacking. In cattle, growth of ovarian follicles from approximately 0.3 to $5 \mathrm{~mm}$ in diameter takes more than $30 \mathrm{~d}$, but subsequent development is rapid, with growth rates of up to $2 \mathrm{~mm} / \mathrm{d}$ detected in larger antral follicles (Lussier et al., 1987). Mossa et al. (2012) reported that dairy cows with a small number of ovarian follicles $(\leq 15)$ had poorer reproductive performance compared with cows with larger numbers of follicles growing during follicular waves, but the existence of a positive association between a high number of ovarian follicles and fertility was not established.

Higher protein degradability in the prepartum diet, indicated by higher plasma urea $\mathrm{N}$, might have led to a smaller largest follicle size for cows in HSB compared with cows in HMP and SB. Development from small antral to large dominant follicles is suggested to take at least 40 to $50 \mathrm{~d}$ (Lopes et al., 2007), so exposure to excessive $\mathrm{N}$ prepartum may continue to impair follicle function and fertility later in the postpartum period. Excess dietary protein has been reported to be deleterious to oocyte development (Butler et al., 1996). Ferguson et al. $(1988,1993)$ reported that BUN concentrations exceeding $20 \mathrm{mg} / \mathrm{dL}$ were associated with reduced conception rates in lactating cows. However, our mean values for urea $\mathrm{N}$ (12 to $14 \mathrm{mg} / \mathrm{dL}$ ) were much lower than that threshold. Lopes et al. (2007) reported that cows diagnosed pregnant had a larger pre-ovulatory follicle size at the day of breeding than cows that were 
not diagnosed pregnant. Pregnancy status and reproductive hormones (e.g., estradiol) were not evaluated in the present study; nonetheless, collectively, our data suggest improved follicular dynamics for cows fed HMP prepartum rather than HSB or SB.

Mobilization of protein itself does not seem to have negative effects on reproduction (Tamminga, 2006). Residues from protein degradation such as urea and ammonia may exert metabolic effects that are often detrimental to reproduction and fertility. Ammonia is believed to play a role starting before ovulation, whereas urea mainly interferes negatively after fertilization (Tamminga, 2006). However, urea is also believed to aggravate the severity of negative energy balance and its effect on fertility by preventing or delaying the start of cyclicity. Additionally, urea has been shown to lower the $\mathrm{pH}$ in the uterine fluid, giving rise to disturbances in follicular development and embryonic growth (Tamminga, 2006).

\section{Interaction Effects}

Part of our objectives was to determine any interactions between prepartum and postpartum MP supply. Few such interactions were detected, providing little evidence in support of the proposal by Lean et al. (2013) that postpartum increases of MP supply would be more important for cows with lower MP intake prepartum, and vice versa. However, the interaction of prepartum diet by postpartum diet for plasma glucose is of interest. Postpartum glucose was greater for cows fed HSB-AMP than for those fed HSB-SB, and was greater for those fed HMP-SB than for those fed HMP-AMP. These differences correspond to the general thesis of Lean et al. (2013), in that greater plasma glucose generally indicates a more favorable metabolic environment. The differences are supported by the relative differences in MP and ME balance among our dietary groups.

The prepartum by postpartum by week interaction for plasma urea $\mathrm{N}$ demonstrated that cows with greater urea prepartum (HSB) or subjected to SB postpartum had greater urea at wk 1 postpartum than cows with lower urea $\mathrm{N}$ prepartum or those fed AMP postpartum. After wk 1, plasma urea $\mathrm{N}$ generally followed the expected response, in that cows fed SB with greater rumen degradability had greater urea $\mathrm{N}$ than cows fed AMP.

\section{CONCLUSIONS}

Feeding greater amounts of MP to dairy cows during the late prepartum period did not improve prepartum or postpartum DMI, milk yield, or milk composition but increased milk fat yield and 4\% FCM yield in wk 1 postpartum. Different sources and amounts of dietary MP postpartum did not improve postpartum DMI, BCS, milk yield, or milk composition except for a tendency to increase milk fat yield, which may be attributed to stimulation of greater loss of BCS by those cows in early lactation. Feeding the animal-marine protein supplement postpartum resulted in greater gross efficiency ( $\mathrm{kg}$ of $4 \% \mathrm{FCM} / \mathrm{kg}$ of DMI) as a result of a numerically lower postpartum DMI combined with a numerical increase in milk fat yield. Feeding AMP prepartum led to improved follicular dynamics postpartum. Few interactions between prepartum and postpartum MP supplies were detected. The increased BCS loss and greater NEFA for cows fed AMP suggest that feeding AMP may have stimulated adipose triglyceride mobilization. Balances of MP and ME are highly interrelated and must be considered concurrently in studies to quantify responses to different MP supply.

\section{ACKNOWLEDGMENTS}

This experiment was supported by funds from H. J. Baker \& Bro. Inc. (Stamford, CT); the Council on Food and Agricultural Research (C-FAR), State of Illinois (Champaign, IL); and state and federal funds appropriated to the Illinois Agricultural Experiment Station (Urbana, IL). The authors have not stated any conflicts of interest.

\section{REFERENCES}

Amanlou, H., T. A. Farahani, and N. E. Farsuni. 2017. Effects of rumen undegradable protein supplementation on productive performance and indicators of protein and energy metabolism in Holstein fresh cows. J. Dairy Sci. 100:3628-3640. https://doi.org/10 $.3168 /$ jds.2016-11794.

Amirabadi Farahani, T., H. Amanlou, N. E. Farsuni, and M. KazemiBonchenari. 2019. Interactions of protein levels fed to Holstein cows pre- and postpartum on productive and metabolic responses. J. Dairy Sci. 102:246-259. https://doi.org/10.3168/jds.2018-14575.

Bell, A. W., W. S. Burhans, and T. R. Overton. 2000. Protein nutrition in late pregnancy, maternal protein reserves and lactation performance in dairy cows. Proc. Nutr. Soc. 59:119-126. https:// doi.org/10.1017/S0029665100000148.

Boucher, S. E., S. Calsamiglia, C. M. Parsons, H. H. Stein, M. D. Stern, P. S. Erickson, P. L. Utterback, and C. G. Schwab. 2009. Intestinal digestibility of amino acids in rumen undegradable protein estimated using a precision-fed cecectomized rooster bioassay: I. Soybean meal and SoyPlus. J. Dairy Sci. 92:4489-4498. https:// doi.org/10.3168/jds.2008-1884.

Butler, W. R., J. J. Calaman, and S. W. Beam. 1996. Plasma and milk urea nitrogen in relation to pregnancy rate in lactating dairy cattle. J. Anim. Sci. 74:858-865. https://doi.org/10.2527/1996 .744858x.

Cadórniga, C., and M. C. López Diaz. 1995. Possible modulation of adipose tissue responsiveness to catecholamines by available dietary protein in dairy cows during early lactation. Reprod. Nutr. Dev. 35:241-248. https://doi.org/10.1051/rnd:19950301. 
Carder, E. G., and W. P. Weiss. 2017. Short- and longer-term effects of feeding increased metabolizable protein with or without an altered amino acid profile to dairy cows immediately postpartum. J. Dairy Sci. 100:4528-4538. https://doi.org/10.3168/jds.2016-12362.

Chan, S. C., J. T. Huber, C. B. Theurer, Z. Wu, K. H. Chen, and J. M. Simas. 1997. Effects of supplemental fat and protein source on ruminal fermentation and nutrient flow to the duodenum in dairy cows. J. Dairy Sci. 80:152-159. https://doi.org/10.3168/jds.S0022 -0302(97)75922-8.

Clark, J. H., T. H. Klusmeyer, and M. R. Cameron. 1992. Microbial protein synthesis and flows of nitrogen fractions to the duodenum of dairy cows. J. Dairy Sci. 75:2304-2323. https://doi.org/10 .3168/jds.S0022-0302(92)77992-2.

Curtis, C. R., H. N. Erb, C. J. Sniffen, R. D. Smith, and D. S. Kronfeld. 1985. Path analysis of dry period nutrition, postpartum metabolic and reproductive disorders, and mastitis in Holstein cows. J. Dairy Sci. 68:2347-2360. https://doi.org/10.3168/jds.S0022 $-0302(85) 81109-7$.

Dann, H. M., N. B. Litherland, J. P. Underwood, M. Bionaz, A. D'Angelo, J. W. McFadden, and J. K. Drackley. 2006. Diets during far-off and close-up dry periods affect periparturient metabolism and lactation in multiparous cows. J. Dairy Sci. 89:3563-3577. https://doi.org/10.3168/jds.S0022-0302(06)72396-7.

Doepel, L., H. Lapierre, and J. J. Kennelly. 2002. Peripartum performance and metabolism of dairy cows in response to prepartum energy and protein intake. J. Dairy Sci. 85:2315-2334. https://doi .org/10.3168/jds.S0022-0302(02)74312-9.

Ferguson, J. D., D. K. Beede, R. D. Shaver, C. E. Polan, J. T. Huber, and P. T. Chandler. 2000. Effects of inclusion of a blended protein product in 35 dairy herds in five regions of the country. J. Dairy Sci. 83:1813-1828. https://doi.org/10.3168/jds.S0022 $-0302(00) 75052-1$.

Ferguson, J. D., T. Blanchard, D. T. Galligan, D. C. Hoshall, and W. Chalupa. 1988. Infertility in dairy cattle fed a high percentage of protein degradable in the rumen. J. Am. Vet. Med. Assoc. 192:659.

Ferguson, J. D., D. T. Galligan, T. Blanchard, and M. Reeves. 1993. Serum urea nitrogen and conception rate: The usefulness of test information. J. Dairy Sci. 76:3742-3746. https://doi.org/10.3168/ jds.S0022-0302(93)77716-4.

Foster, L. B., and R. T. Dunn. 1973. Stable reagents for determination of serum triglycerides by a colormetric Hantzsch condensation method. Clin. Chem. 19:338-340. https://doi.org/10.1093/ clinchem/19.3.338.

Gaines, W.L. 1928. The energy basis of measuring milk yield in dairy cows. Illinois Agricultural Experiment Station, Bulletin 308.

Greenfield, R. B., M. J. Cecava, T. R. Johnson, and S. S. Donkin. 2000. Impact of dietary protein amount and rumen undegradability on intake, peripartum liver triglyceride, plasma metabolites, and milk production in transition dairy cattle. J. Dairy Sci. 83:703-710. https://doi.org/10.3168/jds.S0022-0302(00)74932-0.

Hara, A., and N. S. Radin. 1978. Lipid extraction of tissues with a low-toxicity solvent. Anal. Biochem. 90:420-426. https://doi.org/ 10.1016/0003-2697(78)90046-5.

Hartwell, J. R., M. J. Cecava, and S. S. Donkin. 2001. Rumen undegradable protein, rumen-protected choline and mRNA expression for enzymes in gluconeogenesis and ureagenesis in periparturient dairy cows. J. Dairy Sci. 84:490-497. https://doi.org/10.3168/jds .S0022-0302(01)74499-2.

Husnain, A., and J. E. P. Santos. 2019. Meta-analysis of the effects of prepartum dietary protein on performance of dairy cows. J. Dairy Sci. 102:9791-9813. https://doi.org/10.3168/jds.2018-16043.

Huyler, M. T., R. L. Kincaid, and D. F. Dostal. 1999. Metabolic and yield responses of multiparous Holstein cows to prepartum rumenundegradable protein. J. Dairy Sci. 82:527-536. https://doi.org/10 .3168/jds.S0022-0302(99)75264-1.

Johnson, M. M., and J. P. Peters. 1993. Technical note: An improved method to quantify nonesterified fatty acids in bovine plasma. J. Anim. Sci. 71:753-756. https://doi.org/10.2527/1993.713753x.

Johnson-VanWieringen, L. M., J. H. Harrison, D. Davidson, M. L. Swift, M. A. G. von Keyserlingk, M. Vazquez-Anon, D. Wright, and W. Chalupa. 2007. Effects of rumen-undegradable protein sources and supplemental 2-hydroxy-4-(methylthio)-butanoic acid and lysine $\cdot \mathrm{HCl}$ on lactation performance in dairy cows. J. Dairy Sci. 90:5176-5188. https://doi.org/10.3168/jds.2006-741.

Kokkonen, T. 2014. Investigation of sources of variation in the effect of prepartum protein supplementation on early lactation performance of dairy cows. Livest. Sci. 163:41-50. https://doi.org/10 $.1016 /$ j.livsci.2014.02.008.

Komaragiri, M. V. S., and R. A. Erdman. 1997. Factors affecting body tissue mobilization in early lactation dairy cows. 1. Effect of dietary protein on mobilization of body fat and protein. J. Dairy Sci. 80:929-937. https://doi.org/10.3168/jds.S0022-0302(97)76016-8.

Larsen, M., H. Lapierre, and N. B. Kristensen. 2014. Abomasal protein infusion in postpartum transition dairy cows: Effect on performance and mammary metabolism. J. Dairy Sci. 97:5608-5622. https://doi.org/10.3168/jds.2013-7247.

Law, R. A., F. Young, D. Patterson, D. Kilpatrick, A. Wylie, and C. Mayne. 2009. Effect of dietary protein content on animal production and blood metabolites of dairy cows during lactation. J. Dairy Sci. 92:1001-1012. https://doi.org/10.3168/jds.2008-1155.

Lean, I. J., R. Van Saun, and P. J. DeGaris. 2013. Energy and protein nutrition management of transition dairy cows. Vet. Clin. North Am. Food Anim. Pract. 29:337-366. https://doi.org/10.1016/j .cvfa.2013.03.005.

Lee, C., N. E. Lobos, and W. P. Weiss. 2019. Effects of supplementing rumen-protected lysine and methionine during prepartum and postpartum periods on performance of dairy cows. J. Dairy Sci. 102:11026-11039. https://doi.org/10.3168/jds.2019-17125.

Lines, L. W., and W. P. Weiss. 1996. Use of nitrogen from ammoniated alfalfa hay, urea, soybean meal, and animal protein meal by lactating cows. J. Dairy Sci. 79:1992-1999. https://doi.org/10.3168/jds .S0022-0302(96)76571-2.

Lo, S., J. C. Russell, and A. W. Taylor. 1970. Determination of glycogen in small tissue samples. J. Appl. Physiol. 28:234-236. https:// doi.org/10.1152/jappl.1970.28.2.234.

Lopes, A. S., S. T. Butler, R. O. Gilbert, and W. R. Butler. 2007. Relationship of pre-ovulatory follicle size, estradiol concentrations and season to pregnancy outcome in dairy cows. Anim. Reprod. Sci. 99:34-43. https://doi.org/10.1016/j.anireprosci.2006.04.056.

Lussier, J. G., P. Matton, and J. J. Dufour. 1987. Growth rates of follicles in the ovary of the cow. Reproduction 81:301-307. https:// doi.org/10.1530/jrf.0.0810301.

Mashek, D. G., and D. K. Beede. 2001. Peripartum responses of dairy cows fed energy-dense diets for 3 or 6 weeks prepartum. J. Dairy Sci. 84:115-125. https://doi.org/10.3168/jds.S0022-0302(01)74459 -1 .

Moorby, J. M., R. J. Dewhurst, and S. Marsden. 1996. Effect of increasing digestible undegraded protein supply to dairy cows in late gestation on the yield and composition of milk during the subsequent lactation. Anim. Sci. 63:201-213. https://doi.org/10.1017/ S1357729800014752.

Mossa, F., S. W. Walsh, S. T. Butler, D. P. Berry, F. Carter, P. Lonergan, G. W. Smith, J. J. Ireland, and A. C. O. Evans. 2012. Low numbers of ovarian follicles $\geq 3 \mathrm{~mm}$ in diameter are associated with low fertility in dairy cows. J. Dairy Sci. 95:2355-2361. https: //doi.org/10.3168/jds.2011-4325.

National Research Council. 2001. Nutrient Requirements of Dairy Cattle. 7th rev. ed. Nat. Acad. Sci.

Ørskov, E. R., D. A. Grubb, and R. N. B. Kay. 1977. Effect of postruminal glucose or protein supplementation on milk yield and composition in Friesian cows in early lactation and negative energy balance. Br. J. Nutr. 38:397-405. https://doi.org/10.1079/ BJN19770104.

Pursley, J. R., M. C. Wiltbank, J. S. Stevenson, J. S. Ottobre, H. A. Garverick, and L. L. Anderson. 1997. Pregnancy rates per artificial insemination for cows and heifers inseminated at a synchronized ovulation or synchronized estrus. J. Dairy Sci. 80:295-300. https:/ /doi.org/10.3168/jds.S0022-0302(97)75937-X.

Putnam, D. E., and G. A. Varga. 1998. Protein density and its influence on metabolite concentration and nitrogen retention by Holstein cows in late gestation. J. Dairy Sci. 81:1608-1618. https:// doi.org/10.3168/jds.S0022-0302(98)75727-3. 
Raggio, G., D. Pacheco, R. Berthiaume, G. E. Lobley, D. Pellerin, G. Allard, P. Dubreuil, and H. Lapierre. 2004. Effect of level of metabolizable protein on splanchnic flux of amino acids in lactating dairy cows. J. Dairy Sci. 87:3461-3472. https://doi.org/10.3168/ jds.S0022-0302(04)73481-5.

Santos, F. A. P., J. E. P. Santos, C. B. Theurer, and J. T. Huber. 1998. Effects of rumen-undegradable protein on dairy cow performance: A 12-year literature review. J. Dairy Sci. 81:3182-3213. https://doi .org/10.3168/jds.S0022-0302(98)75884-9.

Santos, J. E. P., J. T. Huber, C. B. Theurer, L. G. Nussio, M. Tarazon, and F. A. P. Santos. 1999. Response of lactating dairy cows to steam-flaked sorghum, steam-flaked corn, or steam-rolled corn and protein sources of differing degradability. J. Dairy Sci. 82:728-737. https://doi.org/10.3168/jds.S0022-0302(99)75290-2.

Studer, V. A., R. R. Grummer, S. J. Bertics, and C. K. Reynolds. 1993. Effect of prepartum propylene glycol administration on periparturient fatty liver in dairy cows. J. Dairy Sci. 76:2931-2939. https://doi.org/10.3168/jds.S0022-0302(93)77633-X.

Tamminga, S. 2006. The effect of the supply of rumen degradable protein and metabolisable protein on negative energy balance and fertility in dairy cows. Anim. Reprod. Sci. 96:227-239. https://doi .org/10.1016/j.anireprosci.2006.08.003.

Tedeschi, L. O., W. Chalupa, E. Janczewski, D. G. Fox, C. Sniffen, R. Munson, P. J. Kononoff, and R. Boston. 2008. Evaluation and application of the CPM Dairy Nutrition model. J. Agric. Sci. 146:171-182. https://doi.org/10.1017/S0021859607007587.

Tyrrell, H. F., and J. T. Reid. 1965. Prediction of the energy value of cow's milk. J. Dairy Sci. 48:1215-1223. https://doi.org/10.3168/ jds.S0022-0302(65)88430-2.
Van Saun, R. J., and C. J. Sniffen. 2014. Transition cow nutrition and feeding management for disease prevention. Vet. Clin. North Am. Food Anim. Pract. 30:689-719. https://doi.org/10.1016/j.cvfa 2014.07.009.

Wattiaux, M. A., D. K. Combs, and R. D. Shaver. 1994. Lactational responses to ruminally undegradable protein by dairy cows fed diets based on alfalfa silage. J. Dairy Sci. 77:1604-1617. https:// doi.org/10.3168/jds.S0022-0302(94)77103-4.

Wildman, E. E., G. M. Jones, P. E. Wagner, R. L. Boman, H. F. Troutt Jr., and T. N. Lesch. 1982. A dairy cow body condition scoring system and its relationship to selected production characteristics. J. Dairy Sci. 65:495-501. https://doi.org/10.3168/jds .S0022-0302(82)82223-6.

Zhang, Q., H. Su, F. Wang, Z. Cao, and S. Li. 2015. Effects of energy density in close-up diets and postpartum supplementation of extruded full-fat soybean on lactation performance and metabolic and hormonal status of dairy cows. J. Dairy Sci. 98:7115-7130. https://doi.org/10.3168/jds.2014-9112.

\section{ORCIDS}

J. H. Clark @ https://orcid.org/0000-0002-3107-5983

F. C. Cardoso $\odot$ https://orcid.org/0000-0003-1025-3231

J. K. Drackley @ https://orcid.org/0000-0002-4560-5594 